e-Jurnal Ilmiah BIOSAINTROPIS (BIOSCIENCE-TROPIC)

Volume 6/ No.: 2 / Halaman 34 - 39 / Januari Tahun 2021

ISSN : 2460-9455 (e) - 2338-2805(p)

\title{
Prevalensi Infeksi Saluran Kemih (ISK) Pada Pasien Di Rumah Sakit Islam (RSI) Unisma Malang Tahun 2018
}

\section{Prevalence of Urinary Tract Infection (UTI) in Patients at Islamic Hospital (RSI) of Unisma Malang on 2018}

\author{
Shinta Mayangsari ${ }_{1,2,3}{ }^{*}$, Nurusan Biologi FMIPA UNISMA, Indonesia
Nour Athiroh $\mathrm{AS}^{2 * *}$, Ratna Djuniwati Lisminingsih ${ }^{3}$
}

\begin{abstract}
ABSTRAK
Infeksi Saluran Kemih (ISK) merupakan infeksi yang umum terjadi di rumah sakit berdampak fungsinya angka morbiditas dan mortalitas yang signifikan. Pola terjangkitnya dari penyebaran kuman bakteri, jamur yang berkembang biak dalam saluran kemih pria maupun wanita dewasa, anak-anak maupun manula. Faktor pendukung ISK dari penyakit penyerta antara lain, hipetensi, diabetes mellitus, asam urat, peralatan medis di rumah sakit (kateter, pispot, dan lain sebagainya). Tujuan dari penelitian ini untuk menghitung prevalensi penderita saluran kemih dan untuk mendiskripsikan faktor pendukung penderita ISK dengan penyakit penyerta di RSI Unisma tahun 2018. Penelitian ini menggunakan metode non-eksperimental dan terdapat hasil prevalensi ISK sebanyak 13,9\%. Perempuan lebih sering menderita ISK dibandingkan dengan pria. Faktor penyebab ISK, ditinjau dari segi usia, jenis, kelamin, keluhan pada penyakit penyerta pada ISK.
\end{abstract}

Kata Kunci : Prevalensi, Infeksi Saluran Kemih (ISK), Penyakit terkait.

\begin{abstract}
Urinary tract infections (UTIS) are common infections in hospitals that have a significant function of morbidity and mortality. The pattern of bacterial germs spread from bacteria, fungi that breed in the urinary tract of men and women, children and seniors. UTI's supporting factors of infectious diseases, among others, hypetension, diabetes mellitus, uric acid, medical equipment in hospitals (catheters, pispots, and so forth). The purpose of this study is to calculate the prevalence of urinary tract sufferers and to describe supporting factors of UTI sufferers with accompanying diseases in RSI Unisma year 2018. The study used non-experimental methods and there were $13.9 \%$ of ISK prevalence results. Women are more often suffering from ISK compared to men. The causes of UTI, are reviewed in terms of age, type, gender, complaints in the accompanying diseases of UTIS.
\end{abstract}

Keywords : Prevalence, Urinary Tract Infection (UTI), Related Diseases

*) Shinta Mayangsari, Jurusan Biologi FMIPA UNISMA, Jl. MT Haryono 193, Malang 65144 Telp. 0895800206669 Email: shintamayang07@gmail.com

${ }^{* *}$ Dr. Nour Athiroh AS., S.Si., M.Kes Jurusan Biologi FMIPA UNISMA, Jl. MT Haryono 193, Malang 65144 Telp.

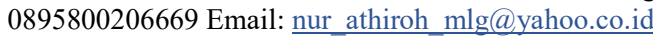

Diterima Tanggal 5 Agustus 2019 - Dipublikasikan Tanggal 25 Januari 2021 
e-Jurnal Ilmiah BIOSAINTROPIS (BIOSCIENCE-TROPIC)

Volume 6/ No.: 2 / Halaman 34 - 39 / Januari Tahun 2021

ISSN : 2460-9455 (e) - 2338-2805(p)

\section{Pendahuluan}

Penyakit infeksi sampai saat ini masih menjadi masalah kesehatan utama di dunia. Hal ini disebabkan karena penyakit yang disebabkan oleh infeksi dikarenakan adanya jenis bakteri, virus, jamur maupun parasit yang berkembangbiak dengan jumlah sekitar 100.000 bakteri/ml urine. Penduduk Indonesia menderita ISK diperkirakan sebanyak 222 juta jiwa dan umumnya menyerang wanita tapi sering juga ditemukan pria. Jumlah pasien terkena ISK di seluruh indonesia sebanyak 100.000-an penduduk pertahun[1].

Prevalensi ISK menurut Riskesdas [2] pada wanita hamil bervariasi diberbagai wilyah dan waktu. Hasil dari studi menunjukkan prevalensi ISK pada masa kehamilan di berbagai negara antara lain sebesar 14\% di Ethiopia, 20\% di Arab Saudi, 7,7\% di India. Di Indonesia, prevalensi ISK pada kehamilan sebesar 30-35\% di Jakata, 5\% di Medan dan 30,2\% di Malang. Tujuan dari penelitian ini adalah menghitung prevalensi penderita saluran kemih dan untuk mendiskripsikan faktor pendukung penderita ISK dengan penyakit penyerta di RSI Unisma tahun 2018.

\section{Material dan Metode}

Penelitian ini menggunakan epidemiologi deskriptif yang bersifat identifikasional. Yang meliputi wawancara pasien dengan kuesioner, analisa data dan dokumentasi rekam medik. Hasil dari keseluruhan pasien yang memeriksa di rumah sakit islam (RSI) Unisma didata pasien yang terkena penyakit infeksi saluran kemih (ISK) dalam kurun tertentu pada tahun 2018. Data yang dikumpulkan hasil dari rekam medik dan hasil wawancara pasien yang yang terdiagnosis pada permasalahn kesehatan pasien.

Rancangan penelitian yang dilakukan adalah : Desain penelitian yang akan digunakan dalam penelitian ini merupakan hasil observasional (non-eksperimental) secara deskriptif. Desain penelitian deskriptif ini menggunakan rancangan potong lintang (Cross-sectional). Peneliti memotret frekuensi dan karakter penyakit serta faktor penelitian pada suatu populasi pada kurun waktu tertentu. Konsekuensinya data yang dihasikan merupakan hasil dari "Prevalensi/Survei". Tujuan studi potong lintang (Cross-sectional), untuk memperoleh gambaran pola infeksi penyakit dan determinan pada populasi.

Parameter Penelitian yang diamati adalah : Kuantitatif (Prevalensi/distribusi ISK dan urin lengkap), Kualitatif (Data responden pasien ISK/ nama / umur / pendidikan / kelamin / jenis ISK dan data responden pasien ISK dengan penyakit penyerta )

Teknik Pengumpulan Data adalah : Pengisian lembar persetujuan dari pihak rumah sakit islam (RSI) Unisma Malang menjadi responden penelitian, mencatat dokumen pasien ISK berdasarkan hasil rekam medik, wawancara dengan pasien ISK menggunakan kuesioner kemudian dilakukan pengolahan data untuk menghitung prevalensi ISK.

Prevalensi ISK berdasarkan rumus berikut menurut Notoatmodjo [3].

\section{Prevalensi : ( Pasien Penderita ISK / Jumlah Pasien Keseluruhan ) x 100\%}

Oleh karena itu prevalensi penderita ISK di Rumah Sakit Islam (RSI) UNISMA Malang pada tahun 2018, yaitu :

Prevalensi Penderita Saluran Kemih (ISK): ( 60/429 ) x 100\%=13,9 \%

\section{Hasil dan Diskusi}

\section{Hasil Penelitian}

Prevalensi Kejadian Infeksi Saluran Kemih (ISK): Berdasarkan dari hasil yang menunjukkan bahwa rata-rata dari 100 pasien yang berobat ke dokter spesialis penyakit dalam di RSI Unisma 
e-Jurnal Ilmiah BIOSAINTROPIS (BIOSCIENCE-TROPIC)

Volume 6/ No.: 2 / Halaman 34 - 39 / Januari Tahun 2021

ISSN : 2460-9455 (e) - 2338-2805(p)

Malang, pada pengambilan data jumlah pasien keseluruhan ISK di RSI Unisma Malang pada bulan Januari sampai dengan Desember tahun 2018. Data diperoleh dari rekam medik pasien dengan populasi dalam penelitian ini sebanyak 429 pasien. Populasi sebanyak 429 pasien ini merupakan pasien yang menjalani tes urin pada Januari - Desember 2018. Hanya 87 pasien dari total populasi yang diduga mengalami infeksi saluran kemih. Dari 87 pasien tersebut, 60 pasien positif menderita infeksi saluran kemih (ISK), sedangkan 27 pasien tidak menderita infeksi saluran kemih berdasarkan hasil urinalisis. Sejumlah 49 pasien mengalami infeksi saluran kemih dengan penyakit penyerta dan 11 pasien tanpa penyakit penyerta. Seluruh pasien infeksi saluran kemih (ISK) tanpa penyakit penyerta selanjutnya menjadi sampel penelitian.

Dari data yang diperoleh dalam penilitian ini dapat diketahui distribusi penyakit infeksi saluran kemih (ISK). Sampel yang telah diperoleh kemudian diolah kembali berdasarkan umur, jenis kelamin dan jenis infeksi saluran kemih (ISK). Data yang diperoleh kemudian diolah menggunakan program Microsoft Excel 2013 dan hasil distribusinya dapat dilihat pada uraian selanjutnya.

Faktor Risiko Infeksi Saluran Kemih dan Distribusi Pasien Berdasarkan Jenis Kelamin: Dari jumlah 60 kasus pasien yang di rawat di Rumah Sakit Islam (RSI) UNISMA sebanyak 33,33\% atau 20 kasus dialami oleh pasien pria dan $66,67 \%$ atau 40 kasus dialami oleh pasien wanita. Wanita cenderung lebih sering menderita ISK dibandingkan pria, karena bakteri dapat menjangkau kandung kemih dengan lebih mudah pada wanita dibandingkan dengan pria. Panjang uretra pada wanita lebih pendek (sekitar 3-5 cm) daripada uretra pria (sekitar 15-18 cm) [4]. Distribusi pasien berdasarkan jenis kelamin dijabarkan dalam Tabel 1.

Tabel 1 Distribusi Pasien Berdasarkan Jenis Kelamin

\begin{tabular}{ccc}
\hline Jenis Kelamin & Jumlah Pasien & Persentase \\
\hline Laki - Laki & 20 & $33,33 \%$ \\
Perempuan & 40 & $66,67 \%$ \\
\hline Jumlah & 60 & $100 \%$ \\
\hline
\end{tabular}

Distribusi Pasien Berdasarkan Usia: Dari 60 kasus yang di rawat di RSI Unisma Malang, angka kejadian ISK terbesar terjadi pada dua kelas usia 36-47 dan 48-59 tahun yang masing-masing sebesar $23,4 \%$ (kedua kelas tersebut berjumlah 46,8\%) karena pada usia tersebut mulai muncul berbagai macam penyakit yang mengakibatkan infeksi saluran kemih sebagai efek sekunder seperti yang dibahas berikut ini. Distribusi pasien berdasarkan usia dijabarkan dalam Tabel 2.

Tabel 2 Distribusi pasien berdasarkan usia

\begin{tabular}{ccc}
\hline Usia & Jumlah & $\begin{array}{c}\text { Persentase } \\
(\mathbf{\%})\end{array}$ \\
\hline $\mathbf{1 2}-\mathbf{2 3}$ & 11 & 18,3 \\
\hline $\mathbf{2 4}-\mathbf{3 5}$ & 13 & 21,7 \\
\hline $\mathbf{3 6}-\mathbf{4 7}$ & 14 & 23,4 \\
\hline $\mathbf{4 8}-\mathbf{5 9}$ & 14 & 23,4 \\
\hline $\mathbf{6 0}-\mathbf{7 1}$ & 4 & 6,7 \\
\hline $\mathbf{7 2}-\mathbf{8 3}$ & 2 & 3,4 \\
\hline $\mathbf{8 4}-\mathbf{9 5}$ & 2 & 3,4 \\
\hline Jumlah & 60 & 100 \\
\hline
\end{tabular}


e-Jurnal Ilmiah BIOSAINTROPIS (BIOSCIENCE-TROPIC)

Volume 6/ No.: 2 / Halaman 34 - 39 / Januari Tahun 2021

ISSN : 2460-9455 (e) - 2338-2805(p)

Insiden ISK dapat menyerang pasien dari segala usia mulai bayi baru lahir hingga orang tua. Dari data yang telah didapat, dua kelas dengan jumlah penderita infeksi saluran kemih terbesar kedua merupakan kelas $12-23$ sebesar $18,3 \%$ dan kelas 24-35 sebesar 21,7\%. Menjelang remaja hingga dewasa insiden ISK bertambah secara signifikan pada wanita mencapai $20 \%$. Faktor risiko yang utama yang berusia 16- 35 tahun yang sangat berkaitan dengan hubungan seksual.

Penyakit Pasien: Dari 60 kasus pasien ISK sebanyak 18,3\% atau 11 kasus ISK tanpa penyakit penyerta dan sebanyak $81,7 \%$ atau 49 kasus ISK dengan penyakit penyerta. ISK dengan penyakit penyerta terbagi lagi sesuai dengan penyakit penyertanya, antara lain : hipertensi, diabetes melitus, dyspepsia, asma, wasir, kolik abdomen serta ISK pada kondisi hamil dan abortus incomplete. Hal ini berarti bahwa ISK cenderung diakibatkan oleh penyakit lain, sehingga merupakan efek sekunder. Distribusi infeksi saluran kemih dengan atau tanpa penyakit penyerta dijabarkan di Tabel 3.

Tabel 3 Distribusi Penyakit Penyerta Pasien Penderita ISK

\begin{tabular}{ccc} 
Diagnosa & Jumlah Pasien & Persentase \\
\hline ISK tanpa penyakit penyerta & 11 & $18,3 \%$ \\
ISK dengan penyakit penyerta & 49 & $81,7 \%$ \\
\hline Jumlah & 60 & $100 \%$ \\
\hline
\end{tabular}

\section{Pembahasan}

Didapatkan dari hasil penelitian skripsi di Rumah Sakit Islam ( RSI) Malang tahun 2018 (Gambar 1), yaitu pada pengambilan data jumlah pasien Infelsi Saluran Kemih (ISK) pada bulan Januari sampai dengan Desember tahun 2018. Adapun faktor penyebab pendukung dari infeksi saluran kemih (ISK), yaitu dapat dilihat dari usia, jenis kelamin, keluhan infeksi saluran kemih (ISK) pada penyakit penyerta. Dapat dilihat data keseluruhan jumlah pasien yang didapatkan dari rekam medik.

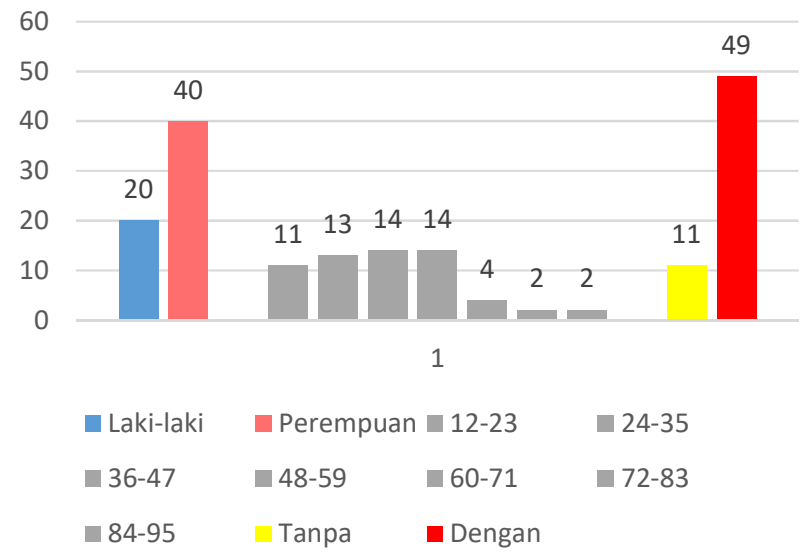

Gambar 1. Distribusi frekuensi penderita ISK berdasarkan jenis kelamin, usia dan penyakit 
e-Jurnal Ilmiah BIOSAINTROPIS (BIOSCIENCE-TROPIC)

Volume 6/ No.: 2 / Halaman 34 - 39 / Januari Tahun 2021

ISSN : 2460-9455 (e) - 2338-2805(p)

Infeksi saluran kemih (ISK ) sering terjadi pada perempuan sebanyak 40 pasien dan pada lakilaki sebanyak 20 pasien. Sering terjadi pada perempuan karena, pada sisten anatomo wanita ukuran uretra wanita lebih pendek sekitar 3-4 cm dibandingkan laki-laki sekitar $20 \mathrm{~cm}$ wanita sistem ekresinya lebih cepat dibandingkan pria. Dilihat dari usia pada 11 jumlah pasien terkait pada usia sekitar 12-23 tahun, 13 jumlah pasien terkait usia sekitar 24-35 tahun, 14 jumlah pasien terkait usia sekitar 26-59 tahun, 4 jumlah pasien terkait usia sekitar 60-71 tahun, 2 jumlah pasien terkait usia sekitar 72-95 tahun. Pada infeksi saluran kemih (ISK) dengan penyakit penyerta sebanyak 49 pasien dan infeksi saluran kemih (ISK) tanpa penyakit penyerta sebanyak 11 pasien, dengan jumlah pasien keseluruhan yang positif (+) infeksi saluran kemih (ISK) sebanyak 60 pasien.. Artinya infeksi saluran kemih (ISK) tanpa penyakit penyerta berarti ISK murni tanpa disertai dengan penyakit lain contohnya, asam urat, hipertensi, gagal ginjal dan lain sebagainya.

Jika Anda mendapat infeksi di saluran kemih, ada beberapa hal yang dapat membantu pasien mengatasi masalah ini. Berikut gaya hidup dan pengobatan rumahan yang dapat membantu pasien menyembuhkan infeksi saluran kemih (ISK) antara lain : Minum 6-8 gelas air sehari. Air yang disaring dan jus stroberi dapat membantu mengobati infeksi saluran kemih (ISK) antara lain ; Jangan lupa untuk menjaga alat kelamin pria dan wanita bersih. Setelah buang air kecil, perempuan harus membersihkan alat kelamin dari depan ke belakang sehingga bakteri dari anus (belakang) tidak dipindahkan ke uretra (depan), hindari mandi, yang membersihkan vagina dengan menyuntikkan air atau cairan pembersih lainnya ke dalam vagina.

Mandi di bawah pancuran dan kurangi mandi. mengurangi risiko, wanita harus buang air kecil dan menyeka sebelum dan sesudah berhubungan seks, hindari penggunaan diafragma dan spermisida sperma, jangan menahan keinginan untuk buang air kecil, segera bersihkan kandung kemih alias, beri tahu dokter jika menggunakan kontrasepsi, minum antibiotik sampai benar-benar sembuh, jika usia anak suka mandi di bak mandi air panas atau menggunakan sabun yang kuat pastikan area genital yang bersih dibilas secara menyeluruh. Karena area genital yang tidak bersih menyebabkan anak terpapar ISK. Setelah iritasi dimulai, akan terasa sakit jika ia kencing, menyebabkan anak menahan air kencingnya. Jaga agar dasar anak bersih dan kering. Ganti popok (untuk anak-anak) saat basah atau kotor., ganti celana setiap hari dan setiap kali basah atau kotor. Kenakan celana dalam katun dan hindari celana ketat, bersihkan penis dengan air setiap hari. Jika penis tidak disunat, tarik kembali kulup untuk membersihkan kerak atau bakteri. Pembersihan kulup penis biasanya harus dibersihkan sekali sehari [5].

\section{Kesimpulan}

Prevalensi infeksi saluran kemih (ISK) di Rumah Sakit Islam (RSI) UNISMA Malang tahun 2018 sebesar 13,9\%. Beberapa faktor penyebab infeksi saluran kemih (ISK) dapat dilihat dari jenis kelamin, usia dan penyakit terkait. Jenis kelamin merupakan faktor yang lebih besar karena berkaitan dengan anatomi masing-masing jenis kelamin. Infeksi saluran kemih (ISK) juga dipengaruhi oleh faktor usia. Hal ini disebabkan karena pada usia remaja hingga dewasa, cenderung terjadi hubungan seksual. Hubungan seksual merupakan salah satu penyebab infeksi saluran kemih. Pada usia produktif dan dewasa, infeksi saluran kemih juga cenderung terjadi sebagai efek sekunder dari penyakit yang mulai muncul. Infeksi saluran kemih cenderung terjadi sebagai akibat dari penyakit lain dan lebih jarang terjadi tanpa didahului penyakit lain.

\section{Daftar Pustaka}

[1] WHO. 2011. Pencegahan Infeksi Saluran Kemih (ISK) yang Cenderung Menjadi Epidemi di Fasilitas Pelayanan Kesehatan. Jfaktorakarta. 
e-Jurnal Ilmiah BIOSAINTROPIS (BIOSCIENCE-TROPIC)

Volume 6/ No.: 2 / Halaman 34 - 39 / Januari Tahun 2021

ISSN : 2460-9455 (e) - 2338-2805(p)

[2] Mayangsari, S. dan N. Athiroh. 2018. Pemeriksaan Urine Di Laboratorium Rumah Sakit Islam (RSI). Universitas Islam Fakultas MIPA Biologi. Malang.

[3] Notoatmodjo, S. 2014. Ilmu Perilaku Kesehatan. Rineka Cipta. Jakarta.

[4] Murwantini. 2004. Insidensi infeksi saluran kemih pada pasien yang terpasang kateter di IRNA V Paviliun Cendrawasih di RSUD Dr Sardjito. Skripsi. PSIK FK UGM, Yogyakarta.

[5] Assauri, S. 2008. Manajemen Studi Epidemiologi. Edisi Revisi. Lembaga Penerbit Fakultas Kedokteran Universitas Indonesia. Jakarta. 